\title{
エアロゾル化ガスデポジション法によるジルコニア膜の形成(荷電粒子の噴射による)
}

\author{
㴊田英嗣的1, 時崎 栄治的1, 小澤 英一出1, 目義雄的 2 \\ 部有渕田ナノ技研，＝286-0011成田市玉造 2-25-57. \\ 虾虫物質・材料研究機構, テ305-0047つくば市千現1-2-1。
}

\section{Formation of Zirconia Films by the Aerosol Gas Deposition Method (By Jetting of Positive Charged Powder)}

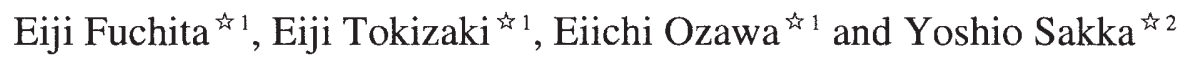 \\ ${ }^{4}$ Fuchita Nanotechnology, Ltd., 2-25-57 Tamatsukuri, Narita 286-0011, Japan. \\ ${ }^{\not}{ }^{2}$ National Institute for Materials Science, 1-2-1 Sengen, Tsukuba 305-0047, Japan.
}

Received April 11, 2011

\begin{abstract}
SYNOPSIS
The aerosol gas deposition method (AGD) is a low temperature method. No heating procedure exists in the AGD process during the formation of the AGD films. We can form even ceramic films by using AGD method. However, the mechanism of synthesizing ceramic film has not been made clear until now. This paper is the first trial to clarify the mechanism by using two kinds of zirconia powder. The experimental results indicated that in wet type zirconia powder the film could be formed in the limited conditions of diameter and the specific surface area of powders although in dry-milled zirconia powder all powders used could form the films. At the same experiments we observed the high temperature phase of zirconia in the film and a light emission phenomenon at the deposition site during AGD process. In this paper, we discuss the formation mechanism of the AGD film at the ambient temperature correlating with the film formation condition, the appearance of the high temperature phase and the light emission.
\end{abstract}

KEY WORDS

high-temperature phase, light emission, zirconia powder, aerosol gas deposition, mean particle size

\section{1 はじめに}

我々は，ナノ粒子をノズルから噴射し，対抗する基板上に 堆積膜を形成する, ガスデポジション(GD)法およびエアロゾ ル化ガスデポジション(AGD)法について, 長年にわたつて研 究開発を進めてきた ${ }^{1-15)}$. いずれの方法も貴金属導体膜形成 分野やエネルギー関連のセラミックス膜形成分野等への応用 が志向されている. AGD法の最も有意な特徵は, 常温でセラ ミックス膜の成膜 ${ }^{16-21)}$ が可能ということであり，加熱源や大 きな真空装置を必要としないという点で, 極めて省エネル ギ一的な特徵を有すことである. 我々は, このAGD装置を用 いることにより, 耐熱分野やイオン電導分野において, その 応用が進められているジルコニア粉 ${ }^{22-27)}$ について, 常温で容 易に緻密成膜を形成できることを明らかにしてきた。本報告 では，ジルコニア粉を用いた結果について報告する．用いた 原料粉は, 市販品で粒子サイズおよび比表面積の異なる, 湿 式化学反応製法で作製されたジルコニア粉および乾式電融・ 粉砕製法で作製したジルコニア粉である. 成膜されたジルコ
二ア膜は, X 線回折を用いて評価しており, その結果ジルコ ニア膜には, 高温相の正方晶が存在することが明らかになっ ている.さらに，噴射堆積時に発光現象も観察された。これ らの事実は, 従来明らかでなかったAGDの成膜メカニズムを 解明する上で重要な因子であると考えられる，そこで，本解 説では, 緻密成膜ができる成膜条件と発光現象について述べ るとともに成膜メカニズムに関する我々の考え方について報 告する.

\section{2 実験方法の概要}

2.1 成膜方法について

Fig.1は, 本実験で使用したAGD装置の概要を示している. 原料粉は密閉したガラス製エアロゾル化容器に入れられてお り, エアロゾル化容器底部に設けられたガス供給ロからガス 供給(今回は窒素ガスを用いている)すると, ガスに吹きあげ られて舞い上がり，エアロゾル化される. 巻き上げられた原 料粉は, 窒素ガスとともに, 搬送管を通して, 真空排気され 


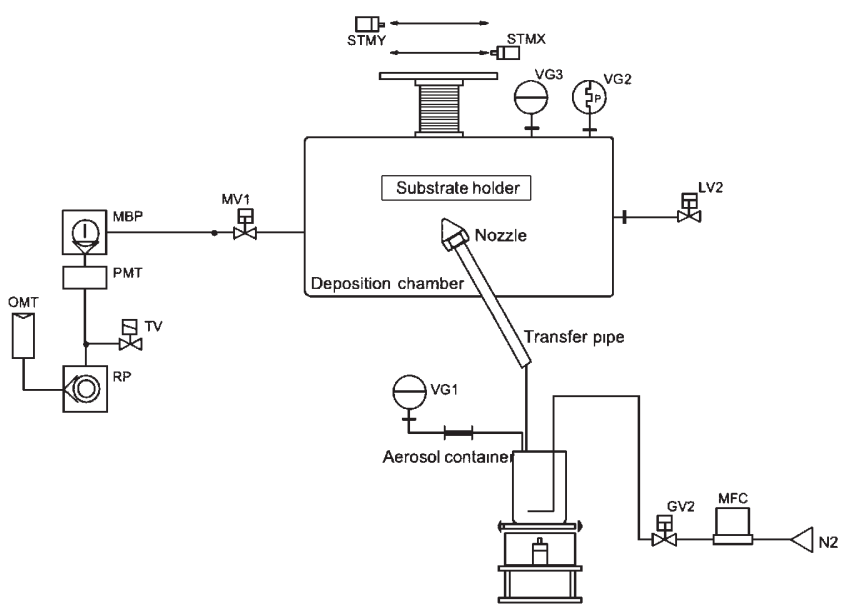

Fig.1 Schematic diagram of the AGD apparatus.

ている膜形成室に送られる。そして，搬送管の先端部に取り 付けられたノズル (幅広ノズル; 幅 $5 \mathrm{~mm}$ および幅 $30 \mathrm{~mm}$ ) 先 端から，対向する基板 (スライドグラス，アルミナおよび $\mathrm{Ni}$ 基合金) へ噴射され, 膜となって堆積する. 基板は, 駆動系 に取り付けられており, プログラム制御により, 目的の成膜 幅に相当する長さを往復運動させている. 例えば $30 \mathrm{~mm}$ 長さ を往復動作 (駆動速度 $1 \mathrm{~mm} / \mathrm{s}$ ) させると, ノズル幅で $30 \mathrm{~mm}$ 長 さの積層膜が形成される.

\section{2 用いた原料粉}

用いた原料粉は, 最初に述べたように, 湿式の化学反応製 法で製造されたジルコニア粉と乾式電融・粉砕製法のジルコ ニア粉の 2 種類である. 一般に, 湿式法のジルコニア粉は産
業利用が進んでいる。一方, 乾式法のジルコニア粉は, 製造 プロセスが簡便で製造コストが安価なため利用分野が拡大し つつあるが, 現行の製造プロセスでは, 精製プロセスがなく, そのため高純度品の製造には不向きと考えられている.二つ の粉は, 粉の形状, 結晶状態, 粒径分布など相違点が多く, こ れが AGD 法による膜形成にどのように影響するかは，AGD 装置の製造者である我々にとって, 知っておくべき重要な点 と考えられた。

実験に使用した湿式粉は, 第一稀元素化学工業製のジルコ ニア粉で, 平均粒子径が $0.47 \mu \mathrm{m} \sim 7.3 \mu \mathrm{m}$ の範囲にあり, 比表 面積は $4.5 \mathrm{~m}^{2} / \mathrm{g} \sim 82.7 \mathrm{~m}^{2} / \mathrm{g}$ の範囲にある 11 種類の原料粉であ る. 一方, 乾式電融・粉砕製法のジルコニア粉は, 同じく第 一稀元素化学工業製の電融法製法ジルコニア粉で, 平均粒子 径が $0.73 \mu \mathrm{m} \sim 10.2 \mu \mathrm{m}$ にあり, 比表面積は $1.5 \mathrm{~m}^{2} / \mathrm{g} \sim 6.1 \mathrm{~m}^{2} / \mathrm{g}$ のもので，異なるスペックの 5 種類の原料粉を入手した。 こ れらの原料粉は, 実験を行う前に脱気用加熱炉を用いて, 原 料粉の乾燥度が同じになるように調整している。

\section{3 特性評価}

Table 1には, 使用した原料粉の特性をまとめている. 粒子 径および比表面積の值は，島津製作所製レーザー回折式粒度 分布測定装置(SALD2100) とフローソーブII 2300 を用いて計 測したものである. 生成されたジルコニア膜の膜断面観察お よび構造解析には, 透過型電子顕微鏡, 走查型電子顕微鏡お よびX 線回折装置 $(\mathrm{CuK} \alpha$ 線) を使用し, 膜厚測定には, マイ クロメーターを使用した。

\section{3 実験および実験結果の詳細}

3.1 湿式化学反応法製ジルコニウム粉の成膜結果 ${ }^{28)}$

Table 1 Characteristics of zirconia powders.

\begin{tabular}{|c|c|c|c|c|c|c|c|c|c|}
\hline \multirow{2}{*}{ No. } & \multirow{2}{*}{ Type } & \multirow{2}{*}{$\begin{array}{c}\text { Mean } \\
\text { particle } \\
\text { size } D_{50} \\
(\mu \mathrm{m})\end{array}$} & \multirow{2}{*}{$\begin{array}{c}\text { Specific } \\
\text { surface } \\
\text { area } \\
\left(\mathrm{m}^{2} / \mathrm{g}\right)\end{array}$} & $\mathrm{ZrO} 2+\mathrm{HfO} 2$ & $\mathrm{SiO} 2$ & $\mathrm{Fe} 2 \mathrm{O} 3$ & $\mathrm{TiO} 2$ & $\mathrm{CaO}$ & \multirow{2}{*}{ Product } \\
\hline & & & & $\%$ & $\%$ & $\%$ & $\%$ & $\%$ & \\
\hline 1 & \multirow{11}{*}{ Wet } & 0.47 & 21.6 & Balance & 0.012 & 0.002 & 0.001 & - & UEP \\
\hline 2 & & 0.58 & 82.7 & Balance & - & - & - & - & UEP \\
\hline 3 & & 2.2 & 5.1 & Balance & 0.002 & 0.002 & 0.001 & 0.004 & EP-5 \\
\hline 4 & & 2.1 & 7.1 & Balance & 0.003 & 0.002 & 0.001 & 0.004 & EP-7 \\
\hline 5 & & 2.1 & 13.0 & Balance & 0.004 & 0.002 & 0.001 & 0.004 & EP-13 \\
\hline 6 & & 2.2 & 22.0 & Balance & 0.004 & 0.001 & 0.001 & 0.004 & EP-22 \\
\hline 7 & & 2.1 & 26.1 & Balance & 0.002 & 0.002 & $<0.001$ & 0.003 & EP-P \\
\hline 8 & & 2.7 & 6.5 & Balance & 0.026 & 0.002 & 0.110 & 0.012 & SPZ-a \\
\hline 9 & & 3.5 & 6.1 & Balance & 0.005 & 0.001 & 0.003 & 0.006 & SPZ-b \\
\hline 10 & & 3.4 & 4.4 & Balance & 0.005 & 0.001 & 0.003 & 0.006 & SPZ \\
\hline 11 & & 7.3 & 9.3 & Balance & 0.005 & 0.002 & 0.001 & 0.001 & WG-8S \\
\hline 12 & \multirow{5}{*}{ Dry } & 0.73 & 6.1 & Balance & 0.14 & 0.12 & 0.17 & - & TMZ-T \\
\hline 13 & & 1.12 & 4.7 & Balance & 0.07 & 0.08 & 0.15 & - & TMZ \\
\hline 14 & & 2.9 & 2.7 & Balance & 0.18 & 0.16 & 0.17 & - & BR-3QZ \\
\hline 15 & & 7.4 & 1.6 & Balance & 0.12 & 0.12 & 0.18 & - & BR-QZ \\
\hline 16 & & 10.2 & 1.5 & Balance & 0.19 & 0.19 & 0.21 & - & BR-12QZ \\
\hline
\end{tabular}




\section{1 .1 成膜結果}

$\mathrm{SPZ}-\mathrm{a}$ (平均粒子径 $\mathrm{D}_{50} ; 2.7 \mu \mathrm{m}$ ，比表面積; $6.5 \mathrm{~m}^{2} / \mathrm{g}$ ) と $\mathrm{SPZ}-\mathrm{b}$ (平均粒子径 $\mathrm{D}_{50} ; 3.5 \mu \mathrm{m}$, 比表面積 ; $6.1 \mathrm{~m}^{2} / \mathrm{g}$ ) という 2 種類の ジルコニア粉を $50 \mathrm{~g}$ から $70 \mathrm{~g}$ 使用して, 巻き上げ量を変化さ せるために, 窒素ガス供給量を $3 \mathrm{~L} / \mathrm{min}$ から $8 \mathrm{~L} / \mathrm{min}$ と変動さ せ，また基材駆動速度を $1 \mathrm{~mm} / \mathrm{s}$ と固定して, 積層繰り返し回 数を 10 回から 150 回とすることにより, 膜厚が $5 \mu \mathrm{m}$ から 24 $\mu \mathrm{m}$ までの白色透明系の緻密な膜を形成することが出来た。 この時に使用したノズルは， $5 \mathrm{~mm}$ 幅のものと $30 \mathrm{~mm}$ 幅のも ので, 基材には主にスライドグラスを用いた。 またエアロゾ ル化室の圧力は， $28 \mathrm{kPa}$ から $47 \mathrm{kPa}$ であった．原料粉は使用 前に $500^{\circ} \mathrm{C} \times 1$ 時間の脱気処理を施したが, 成膜中は当然に無 加熱, 常温である. Table 2 には, 各種ジルコニア粉の成膜条 件および成膜結果がまとめて示されている。

\section{1 .2 ジルコニア粉の性状と成膜との関係}

平均粒子径を 2.1-2.2 $\mu \mathrm{m}$ で一定とし，比表面積の異なる粒 子の場合における成膜の状態を見てみると, 使用した 5 種類 の粉の比表面積, $5.1 \mathrm{~m}^{2} / \mathrm{g}$ から $26.1 \mathrm{~m}^{2} / \mathrm{g}$ の中で, 比表面積 5.1 $\mathrm{m}^{2} / \mathrm{g}$ の場合だけが緻密な成膜が可能であった. その他の比表 面積の大きなものでは, 緻密な膜の形成はできず, 密着力の ない, ポーラスな圧粉体となってしまった。一方，粉の粒径 の影響をみるために，2 種類の微細粉すなわち UEP 粉 (平均 粒子径 $\mathrm{D}_{50} ; 0.47 \mu \mathrm{m}$ および $0.58 \mu \mathrm{m}$, 比表面積; $21.6 \mathrm{~m}^{2} / \mathrm{g}$ および $82.7 \mathrm{~m}^{2} / \mathrm{g}$ ) 使用したものでは，すべてポーラスな圧粉体と なっており, 逆に用いた原料粉の中では, 大きな粒子径である WG-8S 粉 (平均粒子径 $\mathrm{D}_{50} ; 7.3 \mu \mathrm{m}$, 比表面積; $9.3 \mathrm{~m}^{2} / \mathrm{g}$ ) では, 噴射堆積過程において, 粉の堆積と膜剥離が同時に観察され, 結果として成膜されなかった。 以上の結果は, 程ほどの粒径

Table 2 Formation conditions and results of film fabrication (wet-type).

\begin{tabular}{|c|c|c|c|c|c|c|c|}
\hline & $\begin{array}{r}\text { Characte } \\
\text { wet-p }\end{array}$ & $\begin{array}{l}\text { ristics of } \\
\text { owders }\end{array}$ & Formatio & n conditions & Results & $\mathrm{s}$ of film fa & brication \\
\hline No & $\begin{array}{c}\text { Mean } \\
\text { particle }\end{array}$ & $\begin{array}{l}\text { Specific } \\
\text { surface }\end{array}$ & $\begin{array}{c}\mathrm{N}_{2} \text { gas } \\
\text { flow }\end{array}$ & Differential & Quality of & Film & $\begin{array}{c}\text { Deposition } \\
\text { rate }\end{array}$ \\
\hline & $\begin{array}{c}\text { size } D_{50} \\
(\mu \mathrm{m})\end{array}$ & $\begin{array}{c}\text { area } \\
\left(\mathrm{m}^{2} / \mathrm{g}\right)\end{array}$ & $\begin{array}{c}\text { rate } \\
(\mathrm{L} / \mathrm{min})\end{array}$ & & film & $(\mu \mathrm{m})$ & $(\mu \mathrm{m} /$ pass $)$ \\
\hline $1 / 1$ & 0.47 & 21.6 & 5 & 47 & $\begin{array}{c}\text { Green } \\
\text { compact }\end{array}$ & - & - \\
\hline $2 / 1$ & 0.58 & 82.7 & 5 & 47 & $\begin{array}{c}\text { Green } \\
\text { compact }\end{array}$ & - & - \\
\hline $2 / 2$ & 0.58 & 82.7 & 3 & 30 & $\begin{array}{c}\text { Green } \\
\text { compact }\end{array}$ & - & - \\
\hline $3 / 1$ & 2.2 & 5.1 & 8 & 27 & Good & 2 & $0.04 \mu \mathrm{m}$ \\
\hline $3 / 2$ & 2.2 & 5.1 & 12 & 34 & Good & 4 & $0.08 \mu \mathrm{m}$ \\
\hline $4 / 1$ & 2.1 & 7.1 & 8 & 28 & $\begin{array}{c}\text { Peeled } \\
\text { off } \\
\text { partially }\end{array}$ & - & - \\
\hline $4 / 2$ & 2.1 & 7.1 & 12 & 35 & Peeled off & - & - \\
\hline $5 / 1$ & 2.1 & 13 & 8 & 27 & $\begin{array}{c}\text { Green } \\
\text { compact }\end{array}$ & - & - \\
\hline $5 / 2$ & 2.1 & 13 & 12 & 34 & $\begin{array}{c}\text { Green } \\
\text { compact }\end{array}$ & - & - \\
\hline $6 / 1$ & 2.2 & 22 & 6 & 23 & $\begin{array}{c}\text { Green } \\
\text { compact }\end{array}$ & - & - \\
\hline $6 / 2$ & 2.2 & 22 & 12 & 31 & $\begin{array}{c}\text { Green } \\
\text { compact }\end{array}$ & - & - \\
\hline $7 / 1$ & 2.1 & 26.1 & 7 & 59 & $\begin{array}{c}\text { Green } \\
\text { compact }\end{array}$ & - & - \\
\hline $8 / 1$ & 2.7 & 6.5 & 5 & 47 & Good & 24 & $0.8 \mu \mathrm{m}$ \\
\hline $8 / 2$ & 2.7 & 6.5 & 3 & 30 & Good & 6 & $0.6 \mu \mathrm{m}$ \\
\hline $9 / 1$ & 3.5 & 6.1 & 8 & 30 & Good & 20 & $0.13 \mu \mathrm{m}$ \\
\hline $9 / 2$ & 3.5 & 6.1 & 7 & 28 & Good & 5 & $0.1 \mu \mathrm{m}$ \\
\hline $9 / 3$ & 3.5 & 6.1 & 8 & 30 & Good & 20 & $0.17 \mu \mathrm{m}$ \\
\hline $10 / 1$ & 3.4 & 4.4 & 12 & 35 & Good & 10 & $0.2 \mu \mathrm{m}$ \\
\hline $11 / 1$ & 7.3 & 9.3 & 5 & 47 & No film & - & - \\
\hline
\end{tabular}


でかつ比表面積が大きくない原料粉, すなわち数ミクロン粒 子径で数 $\mathrm{m}^{2} / \mathrm{g}$ の比表面積を持つ原料粉が成膜に適した原料粉 であることを意味している.なぜそうした原料粉が適してい るのかが問題と考え，生成された膜を走査型電子顕微鏡 (Fig.2)で調べてみると，基板と堆積膜は良く接合しており， 膜を形成している粒子はおよそ $100 \mathrm{~nm}$ 径の丸みをおびた粒子 で, 原料粉に比べ 10 分の 1 以下に微細化していることが分か る. 原料粉が破砕して堆積しただけでは, 丸みを帯びた理由 が理解できない．強い結合がある以上粒子の表面では原子が 激しく動いて結合しなければならず，室温であることを考え ると説明がむずかしい。

3.2 乾式電融・粉砕製法によるジルコニウム粉の成膜結果 ${ }^{29)}$ 3.2 .1 成膜結果

乾式のジルコニウムでは, 平均粒子径 $\mathrm{D}_{50}$ が, $0.73 \mu \mathrm{m}, 1.12$ $\mu \mathrm{m}, 2.9 \mu \mathrm{m}, 7.4 \mu \mathrm{m}$ および $10.2 \mu \mathrm{m}$ の 5 種類の電融製法ジルコ ニア粉が入手でき，これを使用して成膜したところ，全ての 粉において, 緻密な膜が形成出来た。各種粒子径のジルコニ ア粉の成膜条件および成膜結果については, Table 3に示して
いるが, 窒素ガス供給量を $4 \mathrm{~L} / \mathrm{min}$ から $16 \mathrm{~L} / \mathrm{min}$ とした場合, 膜厚 $6 \mu \mathrm{m}$ から $30 \mu \mathrm{m}$ までの緻密な膜が形成出来た．原料粒子 と堆積膜中の粒子径では, $7.4 \mu \mathrm{m}$ の平均粒子径のジルコニア 粉(BR-QZ)の走査型電子顕微鏡写真(Fig.3 (a)) みみると, $7 \mu \mathrm{m}$ 程度の角ばった不定形な粉砕粒子が多く観察され, 粒度分布 測定值と一致する. そこで, この粉を用いて生成した堆積膜 の断面 SEM 像 (Fig.3 (b), (c)) をみてみると, Fig.3 (b) では膜厚 $25 \mu \mathrm{m}$ の緻密な膜が形成されており，かつ基板との接合も良 好で, 膜表面も平坦である. Fig.3 (c) の膜断面中央部の高倍 率の像によれば, $100 \mathrm{~nm}$ から $200 \mathrm{~nm}$ の粒子が高密度に詰まっ ており，また，この粒子は，原料粉の平均粒子径(一次素粒 子径) $7.4 \mu \mathrm{m}$ に比べて, 50 分の 1 程度に小さくなっている. 膜 構成粒子も湿式法の原料粉の場合と同様に丸みを帯びている. 3.2.2 積層回数および巻上ガス供給量の影響について

$7.4 \mu \mathrm{m}$ の平均粒子径のBR-QZ粉を使用した成膜実験におけ る積層回数および巻上ガス供給量と膜厚との関係を, Fig.4 (a),(b)に示している. 巻上ガス供給量は $4 \mathrm{~L} / \mathrm{min}$ 一定とし, 積 層回数を 50 回から 1000 回まで増加させて成膜すると, 膜厚
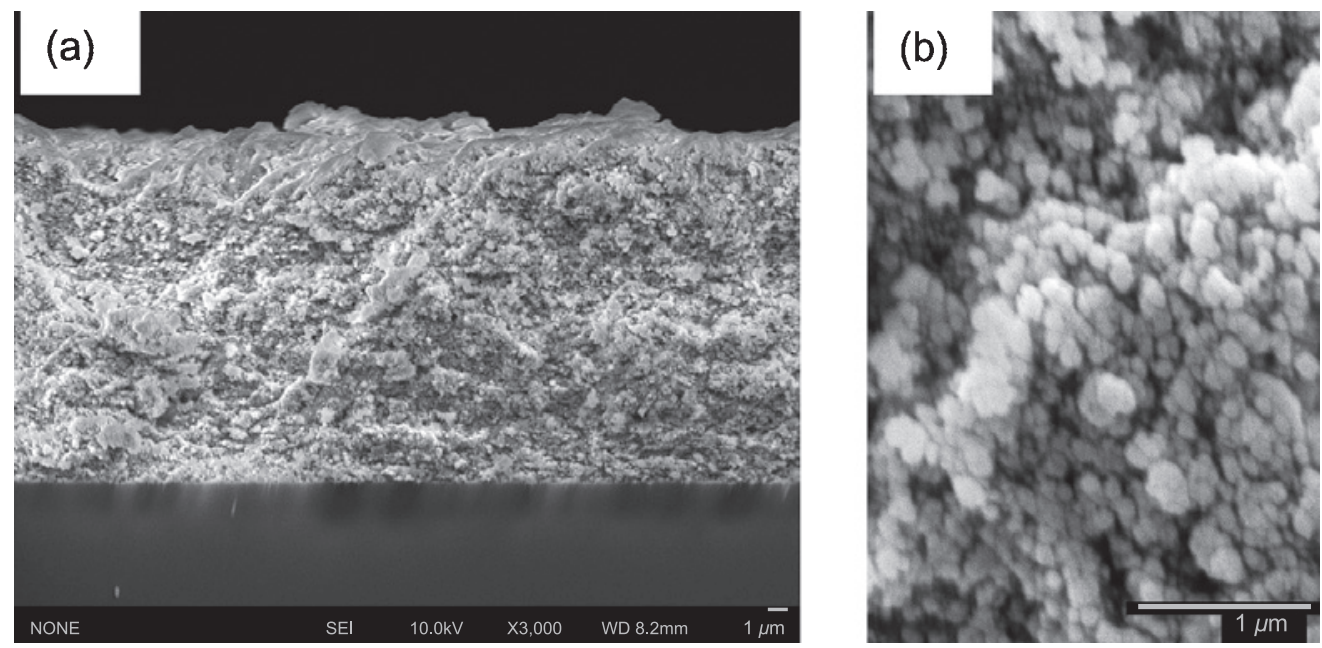

Fig.2 (a) SEM image of cross section of deposited film obtained from SPZ $(2.7 \mu \mathrm{m})$ powder. (b) High-magnification image (No. $8 / 1 ; \mathrm{N}_{2}$ gas flow rate, $5 \mathrm{~L} / \mathrm{min}$ ).

Table 3 Formation conditions and results of film fabrication (dry-type).

\begin{tabular}{|c|c|c|c|c|c|c|c|}
\hline & \multicolumn{2}{|c|}{$\begin{array}{c}\text { Characteristics of } \\
\text { dry-powders }\end{array}$} & \multicolumn{2}{|c|}{ Formation ondition } & \multicolumn{3}{|c|}{ Result of film fabrication } \\
\hline No. & $\begin{array}{c}\text { Mean } \\
\text { particle } \\
\text { size } \mathrm{D}_{50} \\
(\mu \mathrm{m})\end{array}$ & $\begin{array}{c}\text { Specific } \\
\text { surface } \\
\text { area } \\
\left(\mathrm{m}^{2} / \mathrm{g}\right)\end{array}$ & $\begin{array}{c}\text { Amount of } \\
\text { supplied } \\
\mathrm{N}_{2} \text { gas } \\
(\mathrm{L} / \mathrm{min})\end{array}$ & $\begin{array}{c}\text { Differential } \\
\text { pressure } \\
(\mathrm{kPa})\end{array}$ & $\begin{array}{c}\text { Quality of } \\
\text { film }\end{array}$ & $\begin{array}{c}\text { Film } \\
\text { thickness } \\
(\mu \mathrm{m})\end{array}$ & $\begin{array}{c}\text { Deposition } \\
\text { rate } \\
(\mu \mathrm{m} / \mathrm{pass})\end{array}$ \\
\hline $12 / 1$ & 0.73 & 6.1 & 16 & 42 & Good & 28 & 0.56 \\
\hline $13 / 1$ & 1.12 & 4.7 & 12 & 36 & Good & 6 & 0.12 \\
\hline $14 / 1$ & 2.9 & 2.7 & 14 & 38 & Good & 8 & 0.16 \\
\hline $15 / 1$ & 7.4 & 1.6 & 10 & 32 & Good & 14 & 0.28 \\
\hline $16 / 1$ & 10.2 & 1.5 & 8 & 28 & Good & 30 & 0.6 \\
\hline $16 / 2$ & 10.2 & 1.5 & 4 & 22 & Good & 7 & 0.14 \\
\hline
\end{tabular}



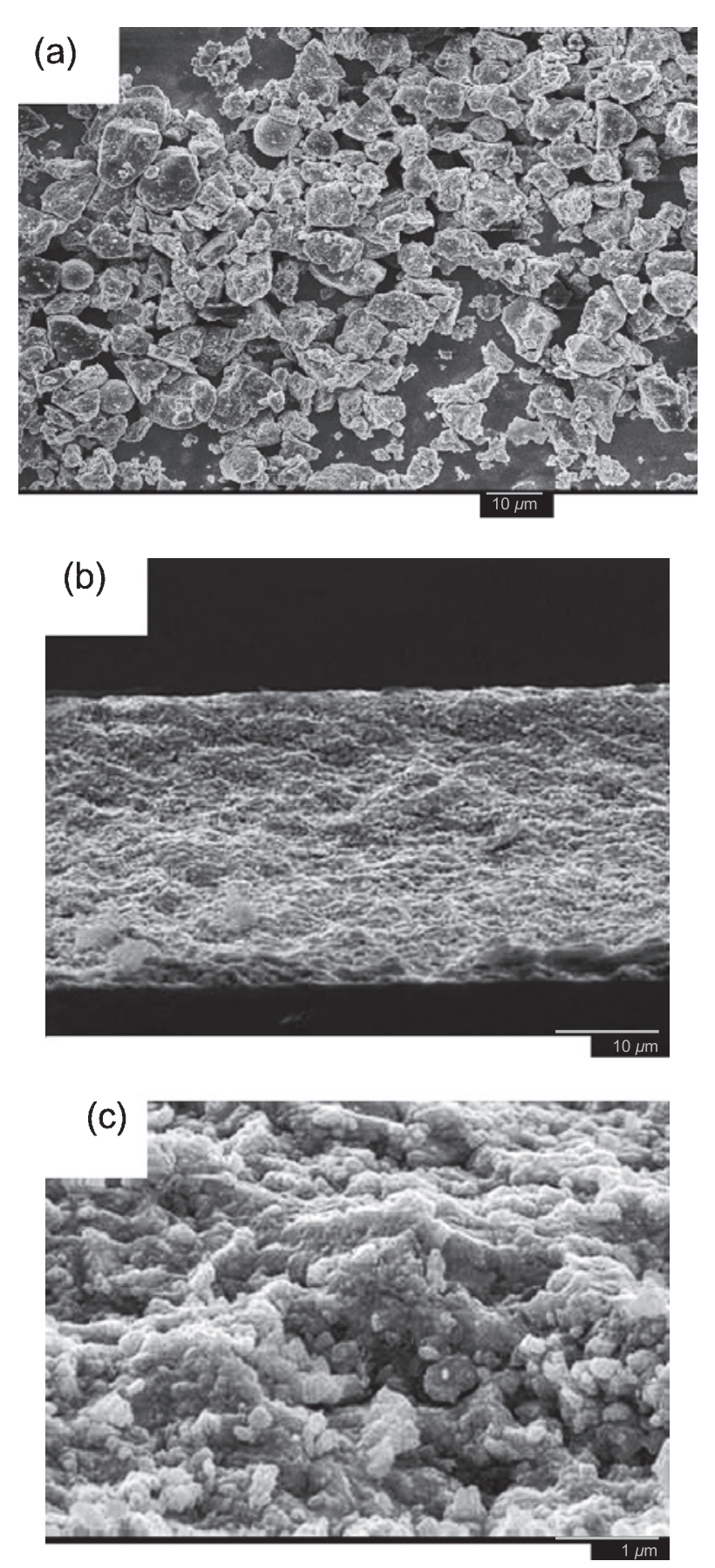

Fig.3 (a) SEM micrograph of the BR-QZ $(7.4 \mu \mathrm{m})$ powder. (b) SEM image of cross section of deposited film obtained from BR-QZ $(7.4 \mu \mathrm{m})$ powder. (c) High-magnification image.

は $1.5 \mu \mathrm{m}$ から $47.5 \mu \mathrm{m}$ まで, 比例的に増加した。積層回数は 50 回一定とし, 巻上ガス供給量を $6,8,10,12,14 \mathrm{~L} / \mathrm{min}$ と増 大させて成膜すると, 膜厚は $3,5,8,12$ および $25 \mu \mathrm{m}$ と増加 し, 巻上ガス供給量の増加と共に, 膜厚は指数関数的に増加 する. この傾向は, Fig.5に示されているように, 5 種類の粉 すべてにおいて同様であり, 増加傾向にある、乾式のジルコ ニウム粉では, 5 種類の粉すべてで成膜可能であり, 巻き上 げガス供給量の増加は, 成膜速度の増加と直結している. 湿 (a)
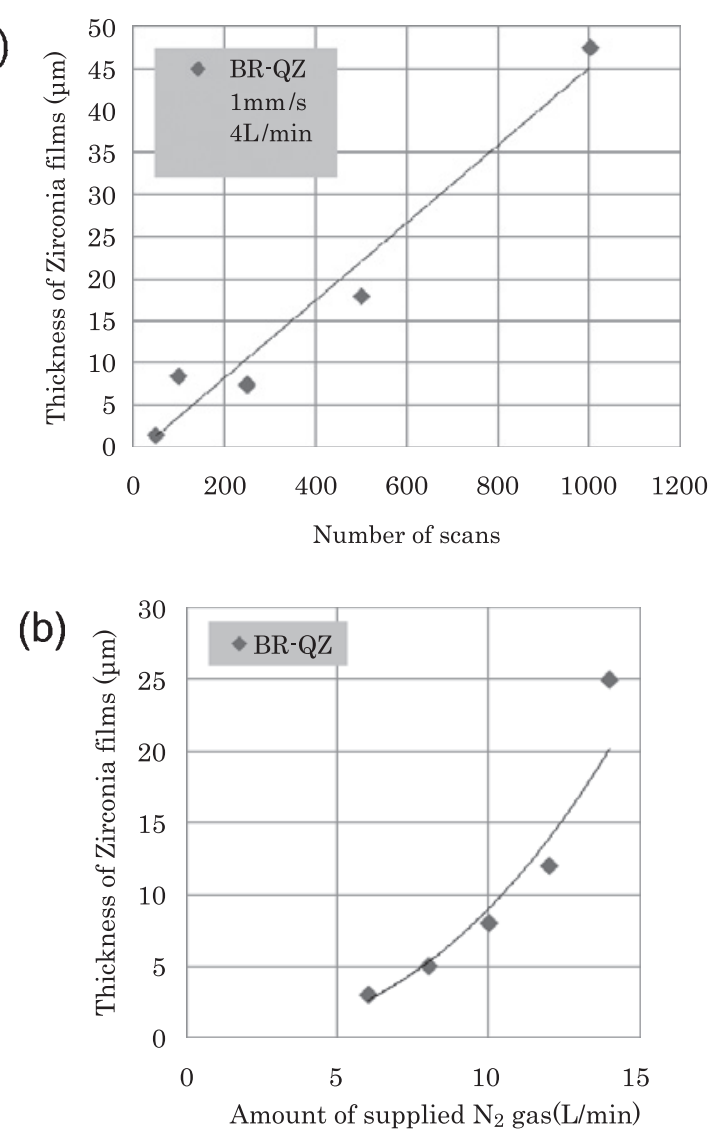

Fig.4 (a) Relationship between the film thickness and the number of scans. (b) Relationship between the film thickness and amount of supplied gas.

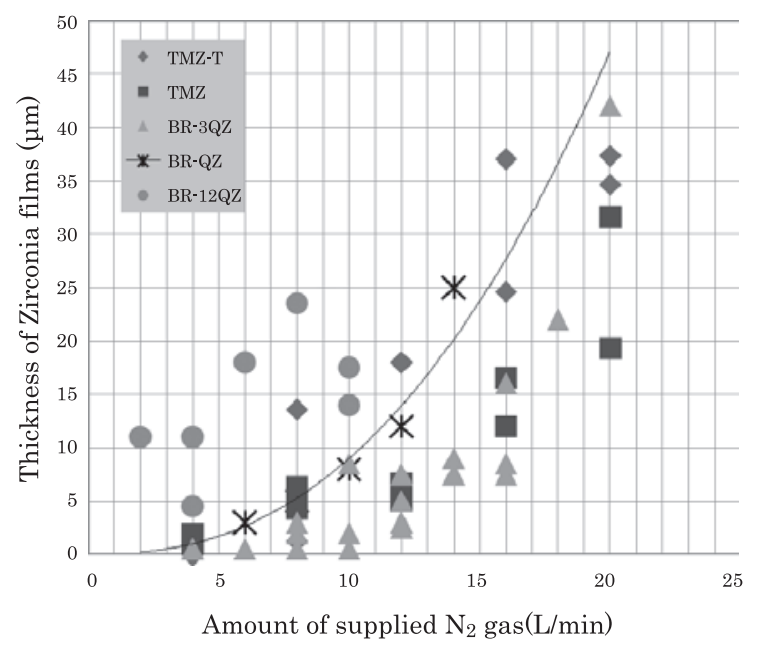

Fig.5 Summery of the relationship between the film thickness and amount of supplied gas.

式法によるジルコニウム粉が, 特定の粒径と比表面積の粉の みで, 成膜可能であるのに比べ, 極めて成膜されやすいとい うことが分かる. 乾式と湿式で何が異なっているのであろう か，以下検討を進めた。 
3.3 原料粉および AGD 膜の構造解析による知見 ${ }^{30)}$

Fig.6には，6組の AGD 成膜および原料粉の XRD のデータ が示されている。ここでは，全ての原料粉は，単斜晶と同定 される。一方， AGD 成膜のXRD ピーク強度において，す心゙ ての膜で $(-111)$ と (111)の強度ピークが逆転し, 形成した膜 では(111)の強度が強くなっている.また，全てのAGD成膜 において, 単斜晶のピークの他に, 正方晶あるいは立方晶と 考えられる高温相のピークが観察される. 特に顕著に表れて いるのが, $7.4 \mu \mathrm{m}$ の粉を使用した場合である. 高温相の同定 のためにラマン分光測定を行ってみると, $7.4 \mu \mathrm{m}$ の粉を使用 した形成膜のラマン分光の結果では単斜晶と正方晶の混合相 と同定された。

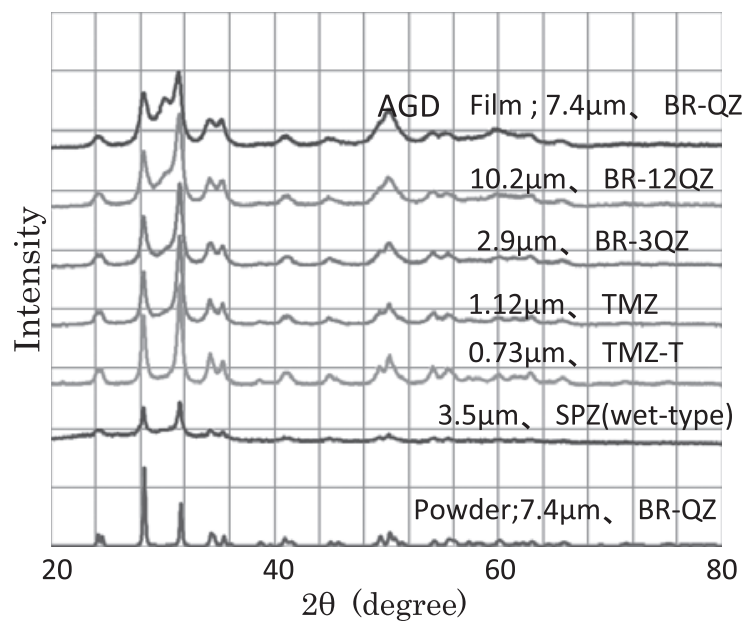

Fig.6 XRD figures of AGD 6-films and starting powder.
次に, 全てのAGD成膜に対して, 単斜晶の (111) 積分強度 と正方晶の (101) 積分強度の比を正確に求めるため, 得られ たXRD データを理学電機製の PDXLソフトを用いてピーク 分離し, 使用した. その解析の一例 $(7.4 \mu \mathrm{m})$ を Fig.7に示して いる. ピーク分離後の単斜晶と正方晶の積分強度比は, Table 4 およびFig.8に示す.これを見ると，原料粉の粒子径が $7.4 \mu \mathrm{m}$ までは積分強度比は比例して増大している.しかし, $10.2 \mu \mathrm{m}$ と更に大きな粒子径になると積分強度比は減少する.しかし, BR-QZ およびTMZ-T, TMZの破断面の SEM 写真 (Fig.9) か らわかるように膜は数 $100 \mathrm{~nm}$ の粒子によって構成されてはい るが, 高温相の存在割合の大小に起因する, 膜構造の変化は, このSEM像からは認められない.しかしながら, $7.4 \mu \mathrm{m}$ の粉

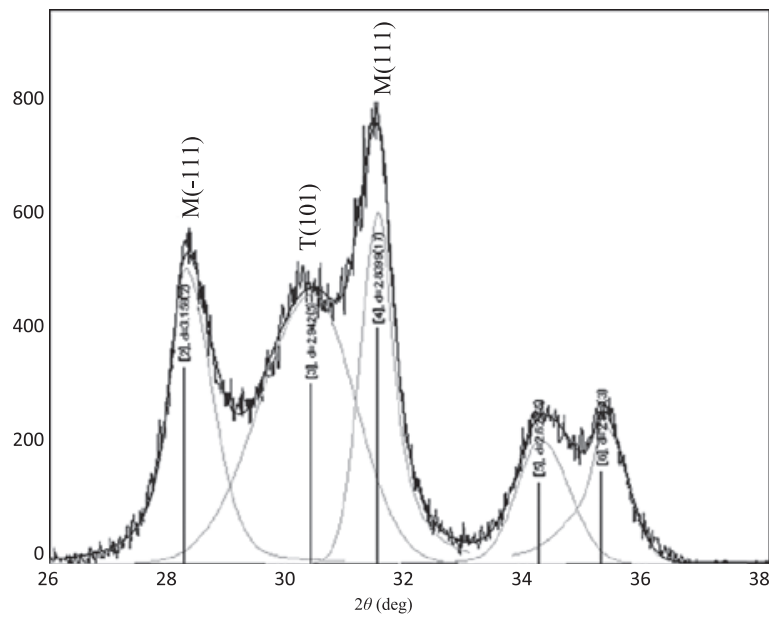

Fig.7 Result of a quantitative analysis for BR-QZ (Rigaku's PDXL).

Table 4 Ratio of the strongest peak of the tetragonal and monoclinic structure of the AGD films.

\begin{tabular}{|c|c|c|c|c|c|c|c|c|c|c|c|}
\hline \multirow{2}{*}{ No. } & \multirow{2}{*}{$\begin{array}{c}\text { Mean } \\
\text { particle } \\
\text { size } D_{50} \\
(\mu \mathrm{m})\end{array}$} & \multirow{2}{*}{$\begin{array}{l}\text { Specific } \\
\text { surface } \\
\text { area } \mathrm{m}^{2} / \mathrm{g}\end{array}$} & \multicolumn{3}{|c|}{ Monoclinic } & \multicolumn{3}{|c|}{ Tetragonal } & \multirow{2}{*}{$\begin{array}{c}\text { Intensity } \\
\text { ratio } \\
\\
\text { T/M }\end{array}$} & \multirow{2}{*}{$\begin{array}{c}\text { Integrated } \\
\text { intensity } \\
\text { raio }\end{array}$} & \multirow{2}{*}{ Product } \\
\hline & & & $2 \theta$ & count & $\begin{array}{l}\text { Integrated } \\
\text { intensity }\end{array}$ & $2 \theta$ & count & $\begin{array}{l}\text { Integrated } \\
\text { intensity }\end{array}$ & & & \\
\hline 1 & 10.2 & 1.5 & 31.4989 & 583.63 & 549.12 & 30.3155 & 146.55 & 270.96 & 25.1 & 49.3 & BR-12QZ \\
\hline 2 & 7.4 & 1.6 & 31.4759 & 414.44 & 351.04 & 30.362 & 315.94 & 629.03 & 76.2 & 179.2 & BR-QZ \\
\hline 3 & 3.5 & 6.1 & 31.5703 & 259.14 & 173.80 & 30.3161 & 28.15 & 47.22 & 10.9 & 27.2 & SPZ-b \\
\hline 4 & 2.9 & 2.7 & 31.4674 & 540.45 & 428.20 & 30.3506 & 46.34 & 70.71 & 8.6 & 16.5 & BR-3QZ \\
\hline 5 & 1.12 & 4.7 & 31.4761 & 592.83 & 420.19 & 30.2596 & 26.26 & 43.18 & 4.4 & 10.3 & TMZ \\
\hline 6 & 0.73 & 6.1 & 31.5192 & 700.62 & 487.89 & 30.4193 & 9.40 & 10.81 & 1.3 & 2.2 & TMZ-T \\
\hline
\end{tabular}




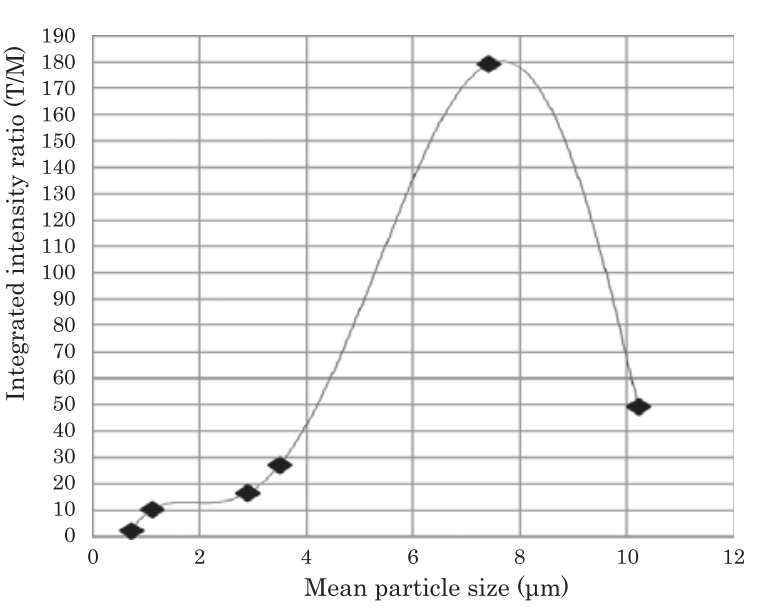

Fig. 8 Relation between the integrated intensity ratio of tetragonal phase to monoclinic phase and the mean diameter of the starting powders.
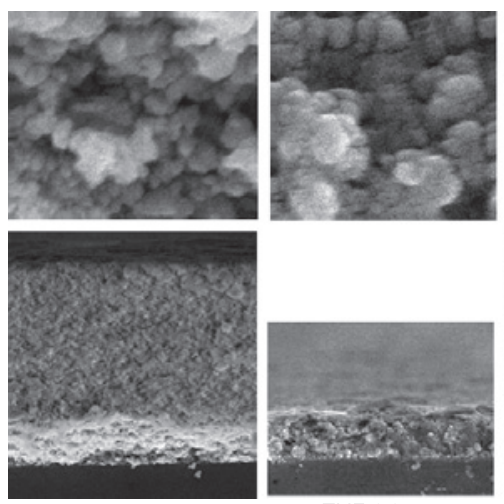

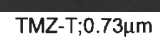

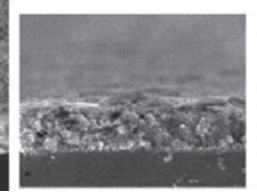

$\mathrm{TMZ} ; 1.12 \mu \mathrm{m}$

Amount of supplied N2 gas; $12 \mathrm{~L} / \mathrm{mIn}$

Number of scans; 50pass
Scanning speed; $1 \mathrm{~mm} / \mathrm{s}$

Fig.9 SEM micrographs of the AGD films.

のコントラスト像, TEM 像 (Fig.10 (c) および (d)) では, 粉は 大きな塊にすぎないが, 膜 (膜を乳鉢で粉砕し, 微細化した もの)の観察では, $100 \mathrm{~nm}$ の塊状粉の内部に $10 \mathrm{~nm}$ 程度の微 細粒子が存在することがわかる(Fig.10(a)および(b)). 我々は この通常では観察できない $10 \mathrm{~nm}$ 程度の極微細粒子の発生が, XRDにおける高温相の存在と結びついているのではないかと 考えている.

3.4 発光現象 ${ }^{30)}$

AGD成膜中に,ノズル先端部から成膜室内壁へ向かってし ばしば放電現象が見受けられる。そのため，ノズル先端部か ら30度の傾きで粒子が噴射される前方のチャンバー壁, およ びその後方のチャンバー壁に, 放電痕が認められる. Fig.11 は，その放電痕の様子を示している。 ノズルから $20 \mathrm{~cm}$ 以上 離れたSUS製内壁にある黒色の付着痕は, 簡単には削り取れ ない. 従ってAGD成膜中に大きな電気的力が働いていること は十分に考えられます。そこで我々は，成膜時のノズル＆基 板近傍をビデオ撮影してみた. Fig.12がそのショット写真で, (a) 明視野像，(b) 暗視野像 (赤外線イメージ)とわかりやすく

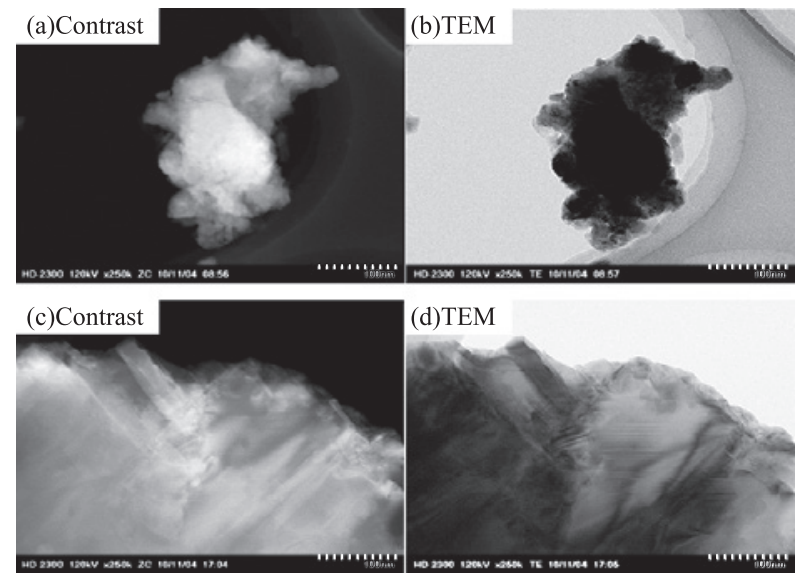

Fig.10 Contrast and TEM images of BR-QZ AGD film ((a) and (b)) and powder ((c) and (d)).

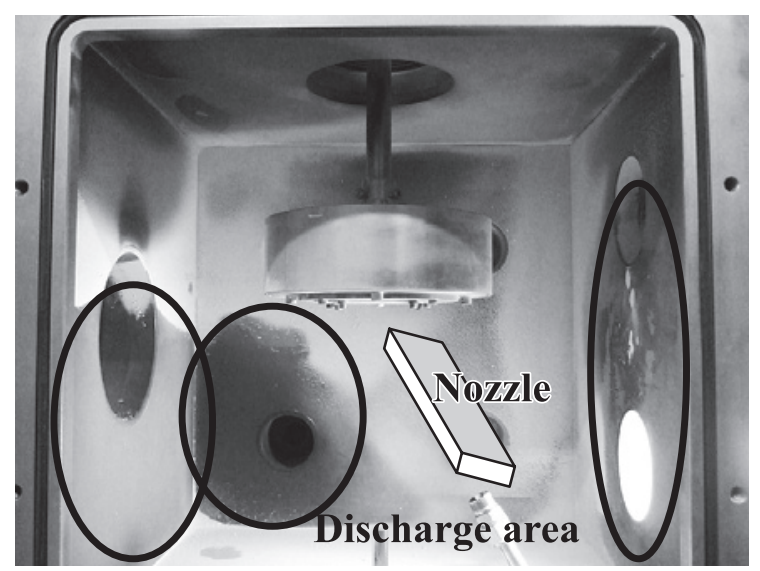

Fig.11 Photograph of electrical discharge phenomena on the inner chamber wall.

するために(c)暗視野のスケッチ図を示している. その結果成 膜中, 基板面で, 発光を伴うことが確認された. 基板面から の発光像が, ガス噴射流とともに流れている様子も確認でき た.

\section{4 考 察}

ジルコニア粉による AGD 成膜実験を通じて, AGD 成膜で は, 用いる原料粉の粒径, 比表面積それに原料粉の製法に起 因する構造が成膜の成否に大きく影響すること, それに成膜 中に発光が生じることが明らかになった，また生成された膜 中の構成粒子の大きさは原料粉の平均径に比べ10分の 1 から 数 10 分の 1 と微小化しており, どうやら高温相も出現し, し かも膜と基板は強固に結合しているということが, 他の研究 者と同様に明快に示されていた。 この結果を見て, 我々が注 目したのは, なぜ乾式のジルコニウム粉が湿式の粉に比べて 容易に成膜するのか, なぜ高温相が出現するのかそれらのこ とと発光はどのように結びついているのかであった. 湿式の 原料粉では平均粒子径 (2 次粒子径) が $2 \mu \mathrm{m}$ 以上の大きさで, かつその比表面積が $6.5 \mathrm{~m}^{2} / \mathrm{g}$ 以下である必要がなぜあるのか, 

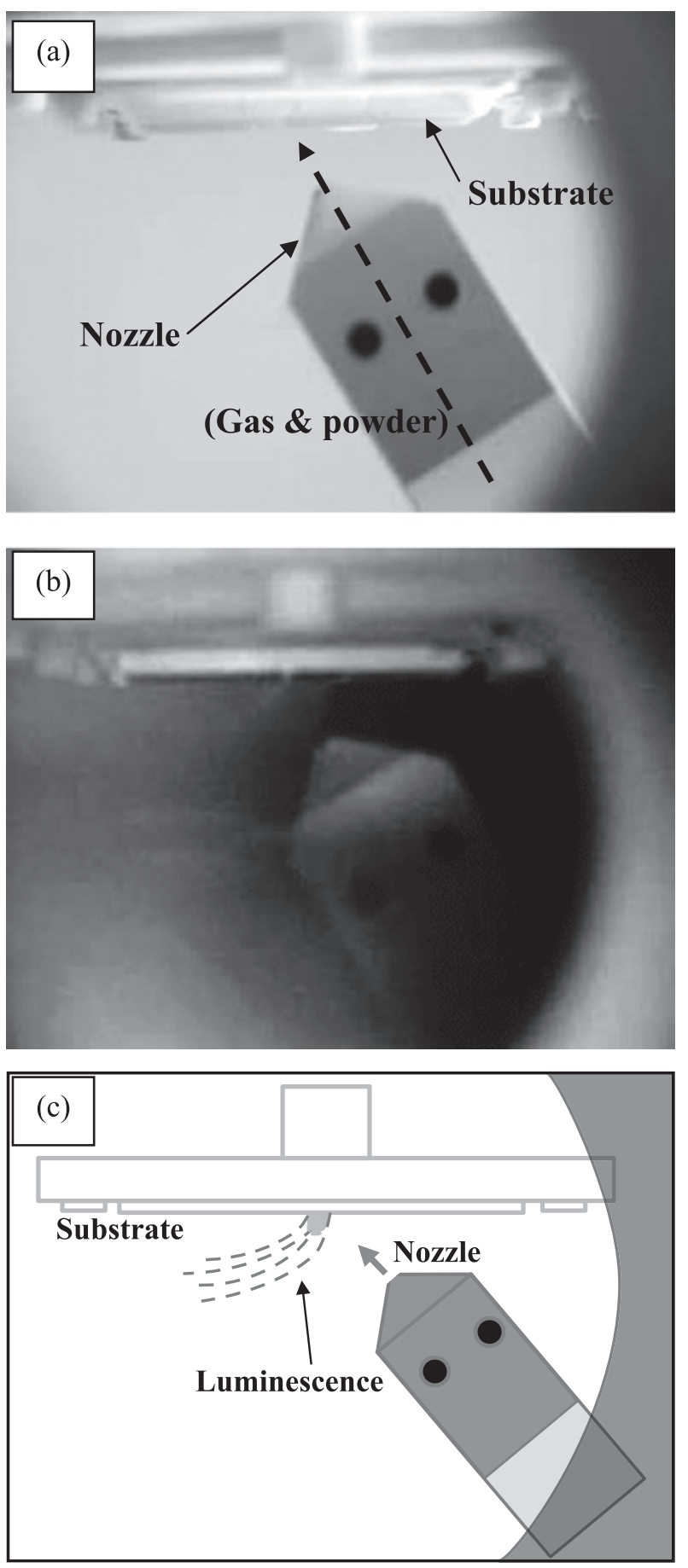

Fig.12 Configuration of the nozzle and substrate and the appearance of light emission. (a) geometry of nozzle and substrate, (b) a view of light emission at a deposition site on a substrate, (c) schematic illustration of light emission.

ノズルから噴射された粒子群が，基板に衝突した際に，その 噴射エネルギーが粒子の再配列に寄与しているものと推察で きるが, 粒径 $2 \mu \mathrm{m}$ 近傍で, 比表面積 $6.5 \mathrm{~m}^{2} / \mathrm{g}$ 以下という条件 が, どのような意味を持っているのかが重要である. そこで, 比較検討のため $2.7 \mu \mathrm{m}$ の原料粉に遊星ボールミル処理 (180 $\mathrm{rpm}, 2$ 時間)を施してから成膜処理を行なうと形成膜は圧粉
体となった. 塊状粒子形態が壊れ, UEP粉と同様な微細粉が 増加したものと推察できる.この成膜メカニズムを考える一 つの考えは, 小さな粒子小よびその凝集体 (塊状ではない)で は, 与えられた噴射エネルギーでは粒子粉の破壊を生じさせ るネルギーが得られず，大きな粒子では，たとえ一部破砕さ れても全体として個々の粒子が接している部分が少なく膜形 成には至ることができないという解釈である. だが, それで は乾式粉ではなぜ 5 種類すべてで成膜可能だったのであろう か. 乾式粉すなわち電融製法粉 (一度高温で溶かして大きな 塊とした後, 粉研分級する乾式製法) では平均粒子径が 0.73 $\mu \mathrm{m}$ から $10.2 \mu \mathrm{m}$ まで，すべて緻密な膜が出来た.いずれの膜 も原料粉の粒径よりも一析以上細かな粒子で構成されている. 湿式粉における考察を当てはめれば, 乾式の場合, いずれの 粉も噴射エネルギーにより, 粒子が破壊され, より細かな粒 子の再配列が形成されていると推察できる. なぜそうなるか について考える必要がある.

電融製法の粉は, 化学反応による湿式製法粉を使用した場 合と異なり, 粒径が $1 \mu \mathrm{m}$ 以下の場合でも緻密膜が出来る.こ のことは, 粒子噴射エネルギーがその構成粒子の一部を粉砕 し, 成膜させるプロセスを仮定した場合, 乾式粉では, 噴射 エネルギーによる破砕がしやすいと考えれば理解できる. 乾 式粉が一度溶融して破砕してできていることを考えると, 個々の粉は多くの欠陥を含有していると考え，これが乾式粉 の成膜し易い原因と考えることができるであろう. しかし， このことと発光および成膜可能と直ちに結びつけることはで きない.

次に, 成膜のメカニズムと関連すると考えられる現象は, 正方晶構造の出現である. ジルコニアの正方晶構造は, 粒子 径が $30 \mathrm{~nm}$ 以下の粒子で, 確認されている ${ }^{31-36)}$. しかしなが ら, Fig.10の SEM 像から, $30 \mathrm{~nm}$ 近傍の粒子が顕著には認め られない. 従って, AGD膜中の正方晶は, さらに小さな粒子 で存在することが考えられる，そこで，成膜構成物を乳鉢で すりつぶし，TEM観察を行なったところ, 特にコントラスト 像にて確認できるが, $100 \mathrm{~nm}$ の粒子の塊の中に, $10 \mathrm{~nm}$ 程度 の粒子が存在することが解った。この小さな粒子が高温相 ピークとなったものと推察している.これについては, 今後, 電子線回折により，その同定を試みる予定である.

原料粉に比べて, はるかに微小な正方晶の存在は, 単に原 料粉が破壊してできたとは考えにくい，我々は，この発生原 因が発光現象之結びついているのではないかと考えている. 発光現象はノズルから噴出した粉粒子とノズルとの摩擦に よって発生した静電気と関係している. 荷電は, 粉が搬送管 内壁と擦れることにより，あるいはまたノズル内壁と擦れる ことにより, 摩擦帯電し発生する. 静電気の発生メカニズム と同じで, 物質同士が擦れ合うと電荷の分配が起こり, 帯電 列の序列によりセラミックス粉はプラスに帯電する.ゅえに, ノズルから噴射する粉は, プラスにチャージしていると考え られる. (当然, 擦り合わせのない中性粉として噴射するもの も存在する) 
噴射粉が衝突する基板面の場所から, 弱い発光が観察され る. $7.4 \mu \mathrm{m}$ の BR-QZ粉を使用した AGD 成膜では，スライド グラス基材およびアルミナ基板への成膜処理中，1積層目か ら発光が目視できる．また，SUS 製基板，銅基板では，それ ぞれ 2 積層目, 4 積層目から発光が目視できる.

ところで, バルク物体が破壞される際に, 破壞電子が放出 されることは, 安田らによって報告されている ${ }^{37-41)}$. ジルコ ニアについても破壊時に電子放出があること, 物質によって その破壊時の放出電子の量が異なること, また, 密度の高い 試料ほど電子放出量が増加することも報告されている.

これらの事実を総合して, 現在のところ我々は, 確固たる 証拠を㨡んでいるわけではないので，仮説の域を出ないが， プラスにチャージされたセラミックス噴射粒子が，ノズルか ら基板へ衝突する AGDの成膜中において, 破壊電子および, あるいはまた摩擦電子が誘発され，その電子がプラスに荷電 した粒子とマイナスの基板との間で加速され発光し，このプ ラズマ中でAGD成膜が行われると考えている. 従って, 粉の サイズ，形状などが，その破壊電子および，あるいはまた摩 擦電子の誘発に影響を及ぼすと考えると, 比表面積の大きな 粉，また $10 \mu \mathrm{m}$ 以上の粉では，緻密な膜が形成できなかった ことは, これらの帯電, 荷電子の効用が㗢いているものと考 える。

一方, 高電圧の印荷無しでも, プラズマが発生することを, 中山らが報告している ${ }^{42-45)}$. 摺動する物質表面から摩擦帯電 され，電子放出によりマイクロプラズマが発生するとの実験 デー夕を報告している.これらのことも, 粉が摩擦帯電して いることの傍証である.

以上により,プラスチャージされた粉の飛来が, AGD プロ セスには，非常に重要であることが示唆される。

\section{5 ま と め}

(1) AGDによる湿式ジルコニア粉の成膜において，粒子径と 比表面積が重要であることが分かった。平均粒子径が 2.1 $\mu \mathrm{m}$ 以上 $3.5 \mu \mathrm{m}$ 以下で，かつその比表面積が $4.4 \mathrm{~m}^{2} / \mathrm{g}$ 以上 $6.5 \mathrm{~m}^{2} / \mathrm{g}$ 以下のジルコニア粉を使用した場合, 緻密な成膜 が可能である.

(2) 湿式微細粉 $(0.5 \mu \mathrm{m})$ および大きな粉 $(7 \mu \mathrm{m})$ では, ポーラスな 圧粉体となるか, 膜が形成されない。また，平均粒子径が $2.1 \sim 2.2 \mu \mathrm{m}$ でも，その比表面積が $7.1 \mathrm{~m}^{2} / \mathrm{g}$ 以上のもので は，圧粉体となった。

（3）電融製法のジルコニア粉, 平均粒子径が $0.73 \mu \mathrm{m}$ から 10.2 $\mu \mathrm{m}$ までのすべての原料粉で, 緻密な膜が形成出来た。ま た, 巻上ガス供給量および積層回数の増加により, 膜厚が 増大することもわかった. 最大で $47.5 \mu \mathrm{m}$ の膜が形成出来 た.

(4) $7.4 \mu \mathrm{m}$ の平均粒子径の原料粉を使用した成膜断面の構成粒 子は，その原料粉より約 500 分の 1 小さい $10 \mathrm{nm \sim 20 \textrm {nm }}$ であり，成膜時に原料粉の粉砕が生じていることがわ かった。
(5) AGDによるジルコニア膜において, 高温相の正方晶が検 出された

(6) 高温相の割合は, 使用粉の粒子サイズに依存し, $7.4 \mu \mathrm{m}$ の BR-QZ粉が極大值を示した.

(7) AGD 成膜中, 発光が確認できた. プラスチャージされた 粉の飛来が, AGD プロセスには, 非常に重要であること が示唆される.

\section{文献}

1) S. Kashu, E. Fuchita, T. Manabe, and C. Hayashi: "Deposition of Ultra Fine Particles Using a Gas Jet", Jpn. J. Appl. Phys., 23(1984)L910-912.

2) C. Hayashi: "Deposition of Ultra Fine Particles Using a Gas Jet", OYO BUTURI, 54(1985)687-693.

3) C. Hayashi: "Ultra-fine Particles and Aerosols", Earozoru Kenkyu, 1(1986)23-29.

4) S. Kashu: ERATO Project, HAYASHI Ultra-Fine Particle, Proceedings, (1984) 11.

5) S. Kashu, Y. Matsuzaki, M. Kaito, M. Toyokawa, K. Hatanaka, and C. Hayashi: "Preparation of Superconducting Thick Films of $\mathrm{Bi}-\mathrm{Pb}-\mathrm{Sr}-\mathrm{Ca}-\mathrm{Cu}-\mathrm{O}$ by Gas Deposition of Fine Powder", Proceedings of the 2nd International Symposium on Superconductivity (ISS89), Tsukuba, Japan, II(1989)413-418.

6) S. Kashu: "Gas Deposition of Ultra-fine Particles", Shinku, 35 (1992)649-653.

7) M. Oda, E. Fuchita, Y. Mihara, and S. Kashu: "Ultra Fine Particle Film by Gas Deposition Method", Denshizairyou, 10 (1994) 1-9.

8) C. Hayashi: "Gas Deposition", Mater. Sci. Forum, 246(1997) 153-180.

9) S. Kashu and Y. Mihara: "Preparation of PZT Deposited Films by Using an Aerosol Jet Printing System and their Electrical Properties", J. Jpn. Soc. Powder Metallurgy, 42(1995)314-317.

10) S. Kashu, Y. Mihara, C. Hayashi, M. Sato, and M. Iijima: "Preparation of Ferroelectric Films of Laminated Polyurea Thin Films onto PZT Deposited Films and their Electric Properties", J. Jpn. Soc. Powder Metallurgy, 42(1995)1411-1414.

11) Y. Mihara and S. Kashu: "Preparation of PZT Thick Films by Using a Jet Printing System", TECHNICAL REPORT of IEICE, (1996) 47-52.

12) Japanese Patent A, S61-87077, (1984).

13) Japanese Patent, $P 3084286,(2000)$.

14) E. Fuchita, K. Setoguchi, I. Katsu, R. Mizutani, and M. Oda: Proc. $8^{\text {th }}$ Int. Microelectronics Conf. (IMC 94), (1994) 20.

15) E. Fuchita, M.Oda, and C. Hayashi: "New Maskless Film Making Method Using Ultra Fine Particles", Materia Japan, 34(1995) 455-460.

16) J. Akedo: "Aerosol Deposition of Ceramic Thick Films at Room Temperature: Densification Mechanism of Ceramic Layers", 
J. Am. Ceram. Soc., 89(2006)1834-1839.

17) H. Ogawa: "Atomistic Simulation of the Aerosol Deposition Method with Zirconia Nanoparticles", Mater. Trans., 47(2006) 1945-1948.

18) Y. Imanaka, N. Hayashi, M. Takenouchi, and J. Akedo: "Aerosol deposition for post-LTCC", J. Eur. Ceram. Soc., 27 (2007) 2789-2795.

19) R. Sakamaki, T. Hoshina, H. Kakemoto, K. Yasuda, H. Takeda, J. Akedo, and T. Tsurumi: "Heat-cycle endurance and in-plane thermal expansion of $\mathrm{Al}_{2} \mathrm{O}_{3} / \mathrm{Al}$ substrates formed by aerosol deposion method", J. Ceram. Soc. Jpn., 116(2008) 1299-1303.

20) J. Akedo: "Room Temperature Impact Consolidation (RTIC) of Fine Ceramic Powder by Aerosol Deposition Method and Applications to Microdevices", J. Thermal Spray Technol., 17 (2008) 181-198.

21) T. Miyoshi: "Preparation of multilayer piezoelectric device by aerosol deposition using a novel detachment method", J. Ceram. Soc. Jpn., 117(2009)899-903.

22) S. Somiya, N. Yamamoto, and H. Yanagida, ed., Advances in Ceramics, 24A(1986).

23) I. O. Golosnoy, A. Cipitria, and T.W. Clyne: "Heat Tranfer Through Plasma-Sprayed Thermal Barrier Coatings in Gas Turbines; A Review of Recnt Work", J. Thermal Spray Technology, 18(2009)809-821.

24) M. Mori, H. Nishimura, H. Yahiro, and Y. Sadaoka: "Potentiometric VOCs detection using 8 YSZ based oxygen sensor", J. Ceram. Soc. Jpn., 116(2008)777-780.

25) O. Vasylkiv, Y. Sakka, Y. Maeda, and V.V. Skorokhod: "Sonochemical Preparation and Properties of Pt-3Y-TZP Nano-Composites", J. Am. Ceram. Soc., 88(2005)639-644.

26) Y. Sakka and K. Hiraga: "Preparation Methods and Superplastic Properties of Fine-Grained Zirconia and Alumina Based Ceramics", Nippon Kagaku Kaishi, (1999)497-508.

27) G. Suárez, Y. Sakka, T.S. Suzuki, T. Uchikoshi, X. Zhu, and E.F Aglietti: "Effect of the starting powders on the sintering of nanostructured $\mathrm{ZrO}_{2}$ ceramics by colloidal processing", Sci. Technol. Adv. Mater., 10(2009)025004.

28) E. Fuchita, E. Tokizaki, and Y. Sakka: "Formation of Zirconia Films by the Aerosol Gas Deposition Method", J. Ceram. Soc. Jpn., 118(2010)767-770.

29) E. Fuchita, E. Tokizaki, E. Ozawa, and Y. Sakka: "Formation of Zirconia Films by Aerosol Gas Deposition Method Using Zirconia Powder Produced by Break-Down Method", J. Ceram. Soc. Jpn., 118(2010)948-951.

30) E. Fuchita, E. Tokizaki, E. Ozawa, and Y. Sakka: "Appearance of high-temperature phase in zirconia films made by aerosol gas deposition method", J. Ceram. Soc. Jpn., 119(2011)271276.
31) R.C. Garvie: "The Occurrence of Metastable Tetragonal Zirconia as a Crystallite Size Effect", J. Phys. Chem., 69(1965) 1238-1243.

32) R.C. Garvie: "Stabilization of the Tetragonal Structure in Zirconia Microcrystals", J. Phys. Chem., 82(1978)218-224.

33) R. Srinvasan, C.R. Hubbard, O.B. Cavin, and B.H. Davis: "Factors Determining the Crystal Phases of Zirconia Poeders; A New Outlook", Chem. Mater., 5(1993) 27-31.

34) E. Djurado, P. Bouvier, and G. Lucazeau: "Crystallite size Effect on the Tetragonal-Monoclinic Transition of Undoped Nanocrystalline Zirconia Studied by XRD and Raman Spectrometry", J. Solid State Chem., 149(2000)399-407.

35) P. Bouvier, E. Djurado, C. Ritter, A.J. Dianoux, and G. Lucazeau: "Low temperature phase transformation of nanocrystalline tetragonal $\mathrm{ZrO}_{2}$ by neutron and Raman scattering studies", Int. J. Inorg. Mater., 3(2001)647-654.

36) S. Shukla and S. Seal: "Thermodynamic Tetragonal Phase Stability in Sol-Gel Derived Nanodomains of Pure Zirconia", J. Phys. Chem. B, 108(2004)3395-3399.

37) J.T. Dickinson, E.E. Donaldson, and M.K. Park: "The emission of electrons and positive ions from fracture of materials", J. Mater. Sci., 16(1981)2897-2908.

38) S.C. Langford, J.T. Dickinson, and L.C. Jensen: "Simultaneous measurement of electron and photon emission accompanying fracture of single-crystal MaO", J. Appl. Phys., 62(1987)14371449.

39) L. Scudiro, J.T. Dickinson, and Y. Enomoto: "The electrification of flowing gases by mechanical abrasion of mineral surfaces", Phys. Chem. Minerals, 25(1998) 566-573.

40) K. Yasuda, M. Shimada, and Y. Matsuo: "Some aspects of photon emission of polycrystalline ceramics during fracture", Phil. Mag. A, 82(2002)3251-3261.

41) T. Shiota, K. Yasuda, and Y. Matsuo: "Correlation between the flexure strength and the photon emission intensity during fracture on single crystal and polycrystalline MgO", Mater. Sci. Eng. B, 148(2008)230-233.

42) K. Nakayama and H. Hashimoto: "Triboemission from various materials in atmosphere", Wear, 147(1991)335-343.

43) K. Nakayama, N. Suzuki, and H. Hashimoto: "Triboemission of charged particles and 1 photons from solid surfaces during frictional damage", J. Phys. D.: Appl. Phys., 25(1992)303308 .

44) K. Nakayama: "Microplasma Generated in a Gap of Sliding Contact", J. Vac. Soc. Jpn., 49(2006)618-623.

45) H. Tanio, S. Nakamura, and T. Ohgaku: "Fractoluminescence and Dislocation Density of Ionic Crystals after X-Ray Irradiation", J. Mater. Sci. Jpn., 57(2008)154-158. 